\title{
PENINGKATAN PENGETAHUAN MAHASISWA KEDOKTERAN TINGKAT 3 UPNVJ DALAM MENCEGAH STUNTING SELAMA KEHAMILAN
}

\author{
Arfiyanti $^{1 *}$, Prasetyo Hadi ${ }^{2}$, Adi Sukrisno ${ }^{3}$, Wendy ${ }^{4}$, Nugrahayu ${ }^{5}$
}

1) Program Studi Ilmu Kedokteran, FK, Universitas Pembangunan Nasional Veteran Jakarta 2) Program Studi Magister Manajemen, FEB, Universitas Pembangunan Nasional Veteran Jakarta

3) Program Studi Ilmu Kedokteran, FK, Universitas Pembangunan Nasional Veteran Jakarta

4) Program Studi Ilmu Kedokteran, FK, Universitas Pembangunan Nasional Veteran Jakarta

5) Program Studi Ilmu Kedokteran, FK, Universitas Pembangunan Nasional Veteran Jakarta *e-mail: arfiyanti.ui@gmail.com

\begin{abstract}
Stunting starts in the womb (11.2\%), between birth to 2 years (60.6\%), and at the age of 2-5 years (28\%). Stunting is a basic process of nutrition. Stunting conditions will disrupt children's physical and cognitive development, delay mental development, and decrease the quality of learning in schools. A survey of level 3 students of the Faculty of Medicine, UPN Veterans Jakarta, found that webinars on topics related to stunting had never been conducted. Conducting a Webinar for level 3 students is to increase students' knowledge about pregnancy and the purpose of stunting and nutrition for pregnant women. The proper nutrition fulfillment during pregnancy can improve the nutritional status of pregnant women and prevent stunting 270 HPK. Webinar's participants were 22\% male and $88 \%$ female. According to the participants, the implementation of the webinar needs to be done routinely $92 \%$ and $8 \%$ reject the routine. Webinar implementation is $100 \%$ beneficial for medical students at UPN Veteran Jakarta. Webinars can increase the knowledge of medical students from $65 \%$ to $72 \%$.
\end{abstract}

Keywords; stunting 270 HPK; pregnant women; malnutrition; prevention; webinar.

\begin{abstract}
Abstrak
Stunting di mulai dari dalam Rahim (11.2\%), antara lahir hingga 2 tahun (60.6\%), dan pada usia 2- 5 tahun (28\%). Stunting merupakan proses kumulatif kekurangan nutrisi. Kondisi stunting akan mengganggu perkembangan fisik dan kognitif anak, keterlambatan perkembangan mental, serta penurunan kualitas belajar di sekolah. Survey pada mahasiswa tingkat 3 fakultas Kedokteran UPN Veteran Jakarta ditemukan webinar dengan topik kehamilan hubungannya dengan nutrisi ibu hamil dan stunting, belum pernah dilakukan. Tujuan melakukan Webinar pada mahasiswa adalah untuk meningkatkan pengetahuan mahasiswa tingkat 3 kedokteran UPNVJ mengenai kehamilan dan hubungannya dengan stunting serta nutrisi ibu hamil. Pemenuhan nutrisi yang tepat selama kehamilan dapat meningkatkan status gizi ibu hamil dan mencegah stunting 270 HPK. Peserta webinar berjenis kelamin laki laki $22 \%$ dan perempuan $88 \%$. Menurut peserta webinar, Pelaksanaan webinar perlu dilakukan secara rutinas $92 \%$ dan menolak rutinitas $8 \%$. Pelaksanaan webinar bermanfaat bagi mahasiswa kedokteran tingkat 3 Upn Veteran Jakarta $100 \%$. Webinar dapat meningkatkan pengetahuan mahasiswa kedokteran dari $65 \%$ menjadi $72 \%$
\end{abstract}

Kata Kunci: stunting 270 HPK;ibu hamil ; malnutrisi; pencegahan; webinar.

\begin{tabular}{l|l|l} 
Submitted: $2021-09-23$ & Revised: $2021-10-26$ & Accepted: $2021-10-30$
\end{tabular}

\section{Pendahuluan}

Seorang anak dikatakan stunting jika pengukuran panjang atau tinggi badannya menurut usia di bawah -2 SD berdasarkan kurva standar pertumbuhan anak WHO 2006 (de Onis and Branca, 2016). Stunting merupakan proses kumulatif yang berawal dari kandungan dan berlanjut hingga masa anak - anak (Prendergast AJ, Humphrey JH,2014).

Stunting akan menyebabkan keterlambatan perkembangan mental, penurunan kualitas belajar di sekolah, mengganggu perkembangan fisik dan kognitif anak (De Onis et al,2013), performa pendidikan, kemampuan verbal dan IQ rendah (Nahar et al, 2019).

Keadaan gizi ibu hamil yang baik akan menjamin pertumbuhan janin dan kelahiran bayi yang sehat, cadangan gizi pasca-kelahiran bagi ibu, serta produksi air susu ibu yang mencukupi untuk memenuhi kebutuhan bayi pada awal usia kehidupannya sehingga secara fisik dan intelektualitas dapat tumbuh kembang dengan sehat dan produktif (Christian P, Stewart CP.,2010). 
Selama kehamilan diet wanita diperlukan untuk menjamin kecukupan kalori dan memenuhi kebutuhan mikronutrien (Williamson CS, 2006; Royal College of Obstetricians and Gynecologists, 2010).

Anak dengan konsumsi makanan rendah energy dan protein ditemukan lebih pendek dan ringan dibanding dengan anak yang mengonsumsi makanan cukup energi dan protein (Mal-ed Network Investigators. 2017).

Otak memiliki kebutuhan akan energi yang besar saat di awal periode anak-anak dan umumnya pertumbuhan otak yang cepat terjadi di 2 tahun pertama kehidupan. Keadaan kurang gizi mempengaruhi area otak yang mengatur kemampuan kognitif, memori dan kemampuan lokomotor (Prendergast AJ, Humphrey JH.,2014).

Defisiensi iodium saat kehamilan dapat menyebabkan kretin dan berpengaruh pada fungsi kognitif. Defisiensi iodium pada janin disebabkan oleh defisiensi iodium pada ibunya. Kondisi ini dikaitkan dengan meningkatnya insiden "lahir mati", aborsi dan ketidaknormalan bawaan, semua ini dapat dihindari dengan intervensi yang tepat (Danton-Hill, I.,1998). Bahan makanan sumber iodium terutama terdapat pada makanan laut seperti udang, ikan tuna (Erick M.2008).

Studi lain melaporkan bahwa defisiensi mikronutrien, seperti $\mathrm{Zn}$, tembaga, dan besi, berhubungan dengan efek teratogenic, supresi imunitas, dan hambatan pertumbuhan janin (Wilson RL, Bianca-Miotto T, Leemaqz SY, Grzeskowiak LE, Dekker GA, and Roberts CT, 2018).

Defisiensi Cu selama masa kehamilan diketahui menjadi penyebab pada ataksia enzotik, abnormalitas jantung dan otak, dan berakibat fatal hingga kematian janin. Tembaga merupakan mikronutrien yang berperan sebagai salah satu komponen enzim dalam reaksi metabolik, antara lain sintesis senyawa, transportasi oksigen, dan angiogenesis. (Gambling L, Kennedy C, McArdle $\mathrm{HJ}, 2011)$.

Kekurangan zat besi selama masa kehamilan berdampak pada gangguan pertumbuhan dan perkembangan janin (Chawla D., 2015 ;L, Gambling Kennedy C, McArdle HJ, 2011), berat lahir bayi rendah, kelahiran prematur, kematian janin (Chawla D., 2015 ;L, Gambling Kennedy C, McArdle HJ, 2011). Berat badan lahir rendah berhubungan dengan peningkatan tekanan darah saat dewasa (Prendergast AJ, Humphrey JH. 2014; Chawla D., 2015).

Pertumbuhan linier yang cepat saat lahir hingga periode awal anak, berhubungan positif dengan peningkatan tekanan sistolik saat dewasa. Perubahan metabolisme yang terjadi selama janin adalah pengalihan zat gizi yang semula ditujukan untuk pertumbuhan menjadi digunakan untuk mempertahankan fungsi vital. Peningkatan berat badan yang cepat setelah usia 2 tahun dan obesitas akan meningkatkan resiko hipertensi, penyakit kardiovaskular dan diabetes tipe 2 (Prendergast AJ, Humphrey JH. 2014).

Kekurangan zat besi dalam keadaan lanjut menyebabkan pembentukan sel darah merah tidak mencukupi untuk kebutuhan fisiologis tubuh (WHO,2012).

Untuk memenuhi kebutuhan zat besi, seorang ibu hamil memerlukan tambahan zat besi sebesar $1000 \mathrm{mg}$ selama kehamilannya, di mana $300 \mathrm{mg}$ dari jumlah tersebut akan secara aktif ditransfer ke janin dan plasenta, $200 \mathrm{mg}$ akan hilang melalui berbagai proses ekskresi terutama melalui saluran cerna, dan $500 \mathrm{mg}$ sisanya diperlukan dalam proses pembuatan sel darah merah yang berperan penting dalam pemenuhan oksigen, nutrisi, dan tumbuh kembang ibu maupun janin (ACOG,2008; Cunningham FG, et. al.,2014).

Pada dasarnya, ibu hamil mengalami proses hemodilusi yang fisiologis terjadi selama proses kehamilan. Pada kehamilan normal dengan janin tunggal, volume plasma darah akan bertambah hingga 50\% (1000 mL) dan sel darah merah bertambah sekitar 25\% (300 mL) (ACOG, 2008).

Proses hemodilusi dan penambahan eritrosit terutama terjadi di trimester dua ke atas, karenanya, kebutuhan zat besi juga lebih besar pada periode tersebut, dengan penambahan sekitar 6-7 mg/hari (Cunningham FG, et. Al,2014). Pada hampir sebagian besar ibu hamil, jumlah tersebut tidak akan terpenuhi hanya dari cadangan zat besi dan asupan makanan sehari-hari, 
sehingga diperlukan adanya pemberian suplementasi besi, yang memang sudah merupakan bagian dari program asuhan antenatal rutin(WHO,2012 ; ACOG,2008; Cunningham FG, et. al , 2014).

Dianjurkan untuk suplementasi $60 \mathrm{mg}$ besi elemental dan $400 \mathrm{ug}$ asam folat selama kehamilan (WHO,2012; ACOG, 2008;Cunningham FG, etal.,2014). Lama pemberian suplementasi besi dikatakan mencukupi jika diberikan minimal selama 6 bulan. Jika tidak mencapai 6 bulan, pemberian suplementasi dapat diteruskan postpartum atau dosis suplementasi ditingkatkan menjadi $120 \mathrm{mg}$ besi elemental per hari (WHO,2002).

Vitamin $A$, dalam bentuk aktif asam retinoat, diketahui memiliki peran yang penting dalam perkembangan otak (Emmet SD, West Jr. KP., 2014). Selama di dalam kandungan, otak janin memiliki kandungan vitamin $\mathrm{C}$ yang paling tinggi. Kekurangan vitamin $\mathrm{C}$ dalam tahap tersebut akan menyebabkan gangguan pada metabolisme di otak janin. Studi pada hewan telah menunjukkan defisiensi vitamin $\mathrm{C}$ berhubungan dengan hambatan pertumbuhan, dimana kondisi ini akan berakibat pada berat bayi lahir rendah dan gangguan perkembangan otak janin (Schjoldager JG, Paidi MD, Lindblad MM, Birck MM, Kjaergaard AB, Dantzer V, et al., 2015).

Zat gizi penting lainnya bagi ibu hamil adalah vitamin B12. Studi yang dilakukan pada ibu hamil vegetarian yang mengalami defisiensi vitamin B12 akan meningkatkan kecenderungan terjadinya diabetes melitus tipe 2 (Yajnik, CS., Deshpande, SS., Jackson, AA., Refsum, H., Rao, S., Fisher, DJ., et al.,2008).

Kekurangan mikronutrien pada ibu hamil akan mempengaruhi pertumbuhan dan perkembangan fetus serta mempengaruhi masa depan fetus menjadi manusia dengan kelainan pada bagian ginjal, fungsi kardiovaskular, pancreas dan fungsi paru-paru (Christian P, Stewart CP, 2010).

Rendahnya asupan makronutrien, baik pada saat awal kehamilan maupun di akhir kehamilan ternyata meningkatkan risiko terjadinya aterogenesis dini pada anak yang dilahirkan (Gale, CR., Jiang, B., Robinson, SM., Godfrey, KM., Law, CM., Martyn, CN,2006).

Protein memiliki peranan yang penting dalam perkembangan janin, terutama fungsi neurologisnya. Penelitian pada hewan menunjukkan bahwa diet rendah protein selama masa kehamilan pada induk betina berhubungan dengan pertumbuhan dan berat janin, massa otot, berat liver, kadar glikogen di liver, pertumbuhan fisik, dan perkembangan neurologis (Ji Y, Wu Z, Dai Z, Wang X, Li J, Wang B, et al., 2017).

Studi lain melaporkan diet rendah protein selama masa kehamilan secara signifikan menurunkan pertumbuhan fisik dan perkembangan perilaku pada tikus yaitu perilaku depresi dan anxietas, di masa dewasanya (Belluscio LM, Berardino BG, Ferroni NM, Ceruti JM, Canepa ET, 2014). Protein diperlukan untuk memenuhi kebutuhan peningkatan sintesis berbagai sel dan jaringan pada janin (Erick M.,2008).

Malnutrisi saat kehamilan merupakan salah satu penyebab dari komplikasi - komplikasi lainnya seperti anemia, pre-eclamsia, perdarahan dll (Papathakis P C, Singh L N, Manary M J. 2016).

Bappenas RI (2012) telah mencanangkan intervensi gizi terutama pada 1000 hari pertama kehidupan seseorang (1000 HPK). 1000 HPK dimulai dari seseorang berada pada kandungan (+ 270 hari) hingga usia 2 tahun (+ 730 hari).

Gizi tepat selama 1000 HPK, dapat membangun fondasi bagi kemampuan anak untuk tumbuh, belajar, dan berkembang. Kuantitas dan kualitas gizi pada bayi dan anak-anak berperan dalam diferensiasi jaringan dan organ serta memiliki efek kesehatan jangka pendek dan panjang (Grammatikaki and Huybrechts, 2016)48.

Pertumbuhan yang baik pada 2 tahun pertama kehidupan anak, berhubungan dengan prestasi sekolah yang lebih baik ketika dewasa (Cheung YF, Taylor MJ, Fisk NM, Redington AN, Gardiner HM.,2000). 


\section{Metode}

Langkah pertama melakukan survey pendahuluan dan analisis situasi pada mitra. Permasalahan mitra adalah pengetahuan mahasiswa fakultas kedokteran tingkat 3 mengenai kehamilan dan hubungannya dengan stunting serta nutrisi ibu hamil masih perlu ditingkatkan. Mahasiswa belum pernah mengikuti webinar untuk meningkatkan pengetahuan mahasiswa tingkat 3 mengenai kehamilan hubungannya dengan stunting serta nutrisi pada ibu hamil. Untuk meningkatkan pengetahuan mahasiswa supaya bisa dipraktekan di layanan kesehatan ibu dan anak. Perlu dilakukan webinar oleh Tim pengabdian Kepada Masyarakat Fakultas Kedokteran UPN Veteran Jakarta.

FKUPN Veteran Jakarta memiliki dosen yang ahli di bidang dan disiplin ilmu yang berkaitan kehamilan hubungannya dengan stunting dan Nutrisi yaitu dr. Adi Sukrisno,Sp.OG.FMAS., Dra.Arfiyanti,M.Kes, Dr.Nugrahayu Widyawardani, M.Gizi, SpGK., dr.Wendy, Sp.KK.M.Kes. FKUPNVJ menjalankan program kompetitif bidang pengabdian kepada masyarakat dengan kinerja sangat baik.

Langkah kedua para narasumber mempersiapkan materi mengenai ibu hamil hubungannya dengan stunting dan nutrisi ibu hamil. Untuk memperoleh nilai pretest dan posttest yang cepat dipersiapkan program untuk mendapatkan nilai tertinggi, akan mendapatkan hadiah dari panitia.

Langkah ketiga webinar dilaksanakan dengan narasumber webinar dari tim pengabdian masyarakat UPN yaitu dr. Adi Sukrisno,Sp.OG.FMAS., Dra.Arfiyanti,M.Kes, Dr.Nugrahayu Widyawardani, M.Gizi, SpGK., dr.Wendy, Sp.KK.M.Kes. . Bapak Dr.Prasetyo Hadi, SE.,MM.,,CFMP memberikan kata sambutan pada webinar 19 Juli 2021.

Sebelum presentasi, narasumber akan memberikan pretest dan posttest setelah prsentasi. Efektvitas pelaksanaan dilihat dari : manfaat webinar, apakah webinar perlu dijalankan secara rutin, tingkat pengetahuan dan pemahaman serta efektivitas webinar. Perubahan tingkat pengetahuan mahasiswa kedokteran tingkat 3 UPNVJ dilihat dari nilai pre dan pos tes.

Evaluasi dilakukan untuk mengetahui sejauh mana efektivitas webinar mencapai tujuan kegiatan yang telah dicanangkan.

\section{Hasil dan Pembahasan}

Webinar dilaksanakan dengan narasumber dari dosen kedokteran UPNVJ yaitu ; dr. Adi Sukrisno,Sp.OG.FMAS., Dra.Arfiyanti,M.Kes, Dr.Nugrahayu Widyawardani, M.Gizi, SpGK., dr.Wendy, Sp.KK.M.Kes.

Webinar diadakan pada hari senin jam 8.30-13.00, tanggal 19 juli 2021. Bapak Dr.Prasetyo Hadi, SE.,MM.,CFMP memberikan sambutan dalam webinar. Supaya mahasiswa mudah memahami materi yang diterangkan maka dipakai media power point. FKUPNVJ memiliki para ahli di bidang dan disiplin ilmu yang berkaitan dengan stunting sehingga secara institusional FKUPNVJ memiliki kinerja yang sangat baik di dalam menjalankan program kompetitif bidang pengabdian kepada masyarakat.

Pada awal acara webinar dilakukan pretest untuk mengetahui pengetahuan mahasiswa tentang kehamilan dan hubungan zat gizi, maupun dampak kekurangan/kelebihan makro/ mikronutrien dengan kehamilan, yang dapat dilihat pada gambar 1. 


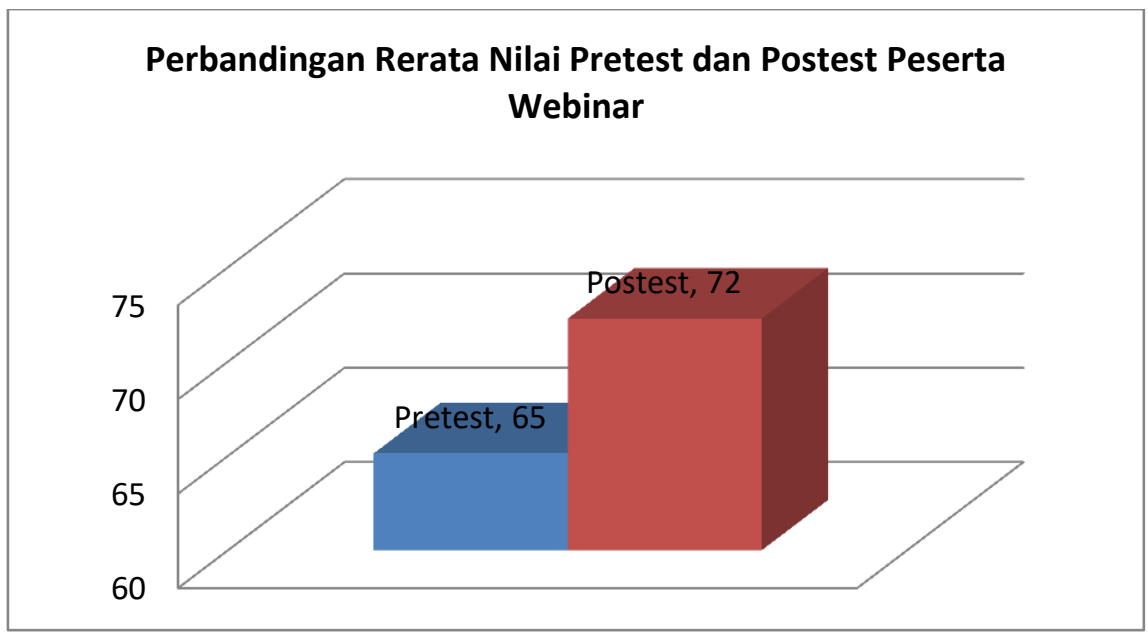

Gambar 1. Nilai pretest dan posttest

Pada awal acara webinar nilai posttest mahasiswa 65. Pada akhir webinar mahasiswa diberi post test untuk mengetahui tingkat pemahaman mahasiswa setelah dilakukan webinar yang dapat dilihat pada gambar 1 . Hasil posttest mahasiswa 72. Tingkat pengetahuan mahasiswa tingkat 3 kedokteran UPN Veteran Jakarta meningkat tentang kehamilan, stunting, dan nutrisi pada ibu hamil. Pengetahuan ini perlu dipahami oleh mahasiswa kedokteran tingkat 3 sebagai dokter di masa depan, agar memiliki dasar ilmiah dalam menanggulangi gangguan yang ditimbulkan oleh stunting.

Menurut hasil webinar, mahasiswa kedokteran tingkat 3 UPN Veteran Jakarta, webinar bermanfaat bagi mahasiswa kedokteran. Diharapkan materi webinar bisa dipraktekan mahasiswa Kedokteran Universitas Pembangunan Nasional Veteran Jakarta di layanan kesehatan ibu dan anak nantinya. Webinar bermanfaat untuk menekan kasus stunting selama kehamilan.

Stunting di mulai dari dalam Rahim (11.2\%), antara lahir hingga 2 tahun (60.6\%), dan pada usia 2- 5 tahun (28\%) (Millward, 2017).

Stunting merupakan proses kumulatif kekurangan gizi yang berawal dari kandungan dan berlanjut hingga masa anak - anak (Prendergast AJ, Humphrey JH,2014)2. Gejala tersering stunting menggambarkan kurang gizi kronis dan diukur sebagai tinggi badan atau panjang badan sesuai umur (Reinhardt and Fanzo, 2014).

Kekurangan mikronutrien pada ibu hamil akan mempengaruhi pertumbuhan dan perkembangan janin serta mempengaruhi masa depan janin menjadi manusia dengan kelainan pada bagian ginjal, fungsi kardiovaskular, pancreas dan fungsi paru-paru (Christian P, Stewart CP, 2010).

Rendahnya asupan makronutrien, baik pada saat awal kehamilan maupun di akhir kehamilan ternyata meningkatkan risiko terjadinya aterogenesis dini pada anak yang dilahirkan (Gale, CR., Jiang, B., Robinson, SM., Godfrey, KM., Law, CM., Martyn, CN,2006).

Materi webinar sangat diperlukan oleh mahasiswa kedokteran dan bisa dipraktekan di layanan kesehatan ibu dan anak. Persentase kebermanfaatan webinar menurut mahasiswa Kedokteran tingkat 3 UPN Veteran Jakarta $100 \%$ seperti yang terlihat dalam gambar 2. 


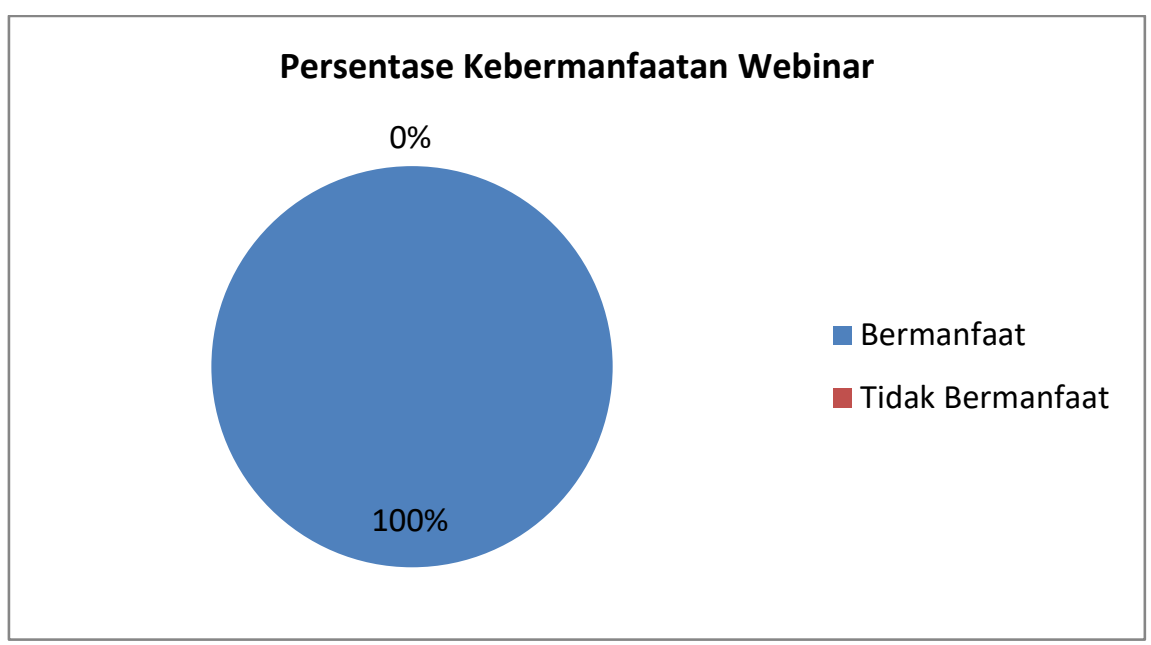

Gambar 2. Manfaat webinar

Bappenas RI (2012) telah mencanangkan intervensi gizi terutama pada 1000 hari pertama kehidupan seseorang (1000 HPK). 1000 HPK dimulai dari seseorang berada pada kandungan (+ 270 hari) hingga usia 2 tahun (+ 730 hari).

Gizi tepat selama 1000 HPK, dapat membangun fondasi bagi kemampuan anak untuk tumbuh, belajar, dan berkembang. Kuantitas dan kualitas gizi pada bayi dan anak-anak berperan dalam diferensiasi jaringan dan organ serta memiliki efek kesehatan jangka pendek dan panjang (Grammatikaki and Huybrechts, 2016).

Pertumbuhan yang baik pada 2 tahun pertama kehidupan anak, berhubungan dengan prestasi sekolah yang lebih baik ketika dewasa (Cheung YF, Taylor MJ, Fisk NM, Redington AN, Gardiner HM.,2000).

Untuk meningkatkan pengetahuan mahasiswa kedokteran tingkat 3 UPN Veteran Jakarta, Persentase webinar perlu jadi rutinitas $92 \%$. Webinar berguna untuk menambah pengetahuan mahasiswa kedokteran tingkat 3 mengenai kehamilan, stunting dan nutrisi ibu hamil. Pada gambar 3. Mahasiswa kedokteran tinggkat 3 menyatakan webinar stunting tidak perlu dilakukan jadi kegiatan rutinitas $8 \%$. Hal ini mungkin karena waktu webinar cukup lama sehingga menimbulkkan kebosanan peserta webinar.

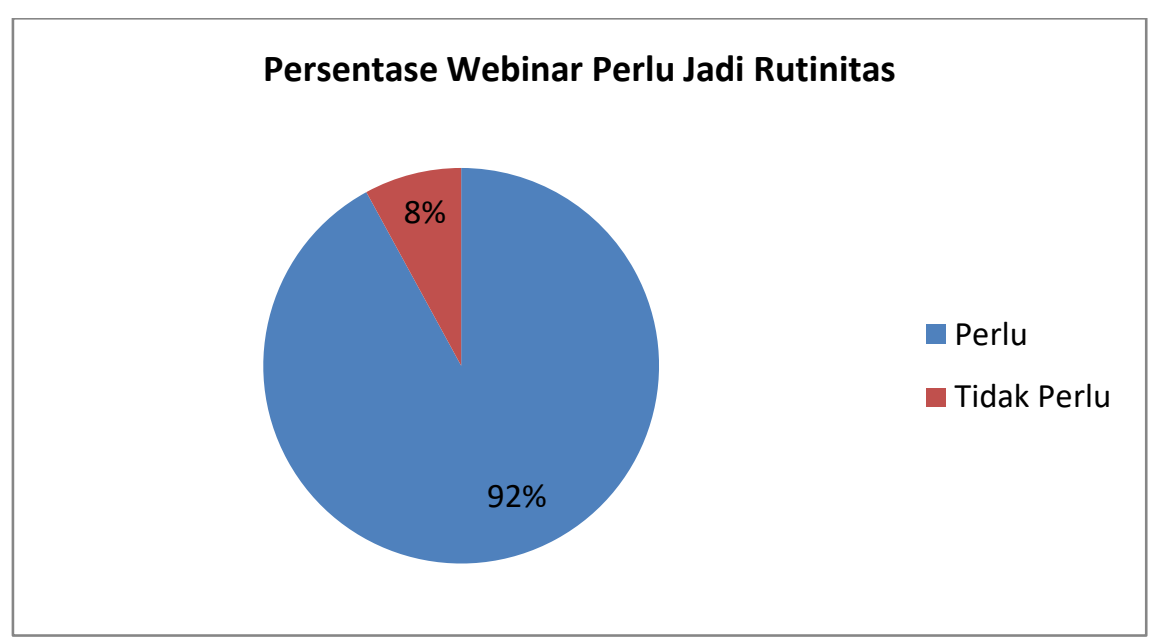

Gambar 3. Webinar perlu jadi rutinitas

Peserta webinar mahasiswa kedokteran tingkat 3 fakultas kedokteran Universitas Pembangunan Nasional Veteran Jakarta terdiri dari perempuan $78 \%$ dan $22 \%$ laki laki. Persentase jenis kelamin peserta webinar dapat dilihat pada gambar 4. di bawah ini. 


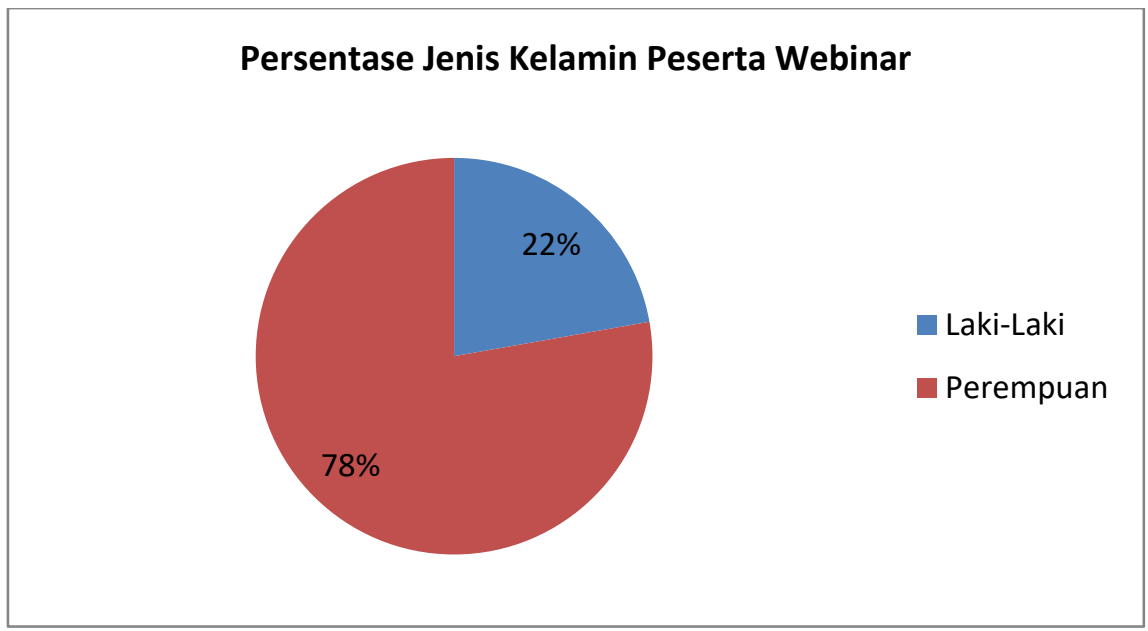

Gambar 4. Jenis kelamin peserta webinar

\section{Kesimpulan.}

Kegiatan webinar ini diikuti peserta $22 \%$ laki laki dan perempuan $78 \%$. Kebermanfaatan webinar memperoleh $100 \%$. Peningkatan pengetahuan mahasiswa dari hasil pretest mahasiswa $65 \%$ menjadi posttest $72 \%$. Persentase Webinar perlu jadi rutinitas $92 \%$ dan tidak perlu jadi rutinitas $8 \%$

\section{Daftar Pustaka}

American College of Obstetricians and Gynecologists, 2008, Anemia in pregnancy, ACOG Practice Bulletin ;112(1):201-207.

BAPPENAS RI. 2012. Pedoman Perencanaan Program Gerakan Sadar Gizi dalam Rangka Seribu Hari Pertama Kehidupan (1000 HPK). Jakarta.

Belluscio LM, Berardino BG, Ferroni NM, Ceruti JM, Canepa ET, 2014. Early protein malnutrition negatively impacts physical growth and neurological reflexes and evokes anxiety and depressive-like behaviors. Physiology \& Behavior; 124: 237-54.

Chawla D., 2015, Fetal effects of maternal iron deficiency. Indian J Pediatr.;82 (12):1080-1

Cheung YF, Taylor MJ, Fisk NM, Redington AN, Gardiner HM.,2000.Fetal origins of reduced arterial distensibility in the donor twin intwin-twin transfusion syndrome. Lancet. 2000;355:11578.

Christian P, Stewart CP.2010. Maternal micronutrient deficiency: fetal development and risk of chronic disease. J Nutr., 140:437-45.

Cunningham FG, et. al.,2014, Williams Obstetrics 24th ed. New York: McGraw-Hill Companies.ACOG, 2008 ; Cunningham FG, et. al.,2014.

Danton-Hill, I., 1998. Solving the Micronutrient problem in Asia Pacific region. Asia Pasific. J. Clin Nutr. $7(3 / 4): 245-255$.

De Onis, M., Dewey, K. G., Borghi, E., Onyango, A. W., Blössner, M., Daelmans, B., Piwoz, E. and Branca, F., 2013, The World Health Organization's global target for reducing childhood stunting by 2025: rationale and proposed actions, Maternal \& Child Nutrition;9: 6-26.

Danton-Hill, I., 1998. Solving the Micronutrient problem in Asia Pacific region. Asia Pasific. J. Clin Nutr. 7 (3/4) : 245-255.

Emmet SD, West Jr. KP.,2014, Gestational vitamin A deficiency: a novel cause of sensorineural loss in the developing world? Medical Hypotheses; 82: 6-10. 
Erick M., 2008. Nutrition during pregnancy and lactation. Dalam: Mahan LK, Escott-Stump SE. Krause's Food and Nutrition Therapy. edisi 12. Missouri: Saunders Elsevier. 2008. hal.16084.

Gale, CR., Jiang, B., Robinson, SM., Godfrey, KM., Law, CM., Martyn, CN.,2006 "Maternal diet during pregnancy and carotid intima-media thickness in children. Arterioscler Thromb Vasc Biol.; 26:1877-82. Available from URL.

Grammatikaki E.and Huybrechts I. 2016. Infants: Nutritional Requirements Encyclopedia of Food and Health, pp.410-417.

Yajnik, CS., Deshpande, SS., Jackson, AA., Refsum, H., Rao, S., Fisher, DJ.,2008, et al. "Vitamin $\mathrm{B} 12$ and folate concentrations during pregnancy and insulin resistance in the offspring: the Pune maternal nutrition study. Diabetologia.; 51:29-38.

L, Gambling Kennedy C, McArdle HJ., 2011, Iron and copper in fetal development. Seminars in Cell \& Developmental Biology;22:637-44.

Mal-ed Network Investigators. 2017, Relationship between growth and illness, enteropathogens and dietary intakes in the first 2 years of life: findings from the MAL-ED birth cohort study. BMJ.Glob Health. 2: e000370

Nahar B., Hossain M., Mahfuz M., Islam M. M., Hossain M. I., Murray-Kolb L E, Seidman J C, Ahmed T., 2019, Early childhood development and stunting findings form MAL-ED birth cohort study in Bangladesh, Maternal \& Child Nutrition. e12864.

Prendergast AJ, Humphrey JH., 2014, The stunting syndrome in developing countries, Paediatr Int Child Health, 2014; 34(4): 250-65.

Reinhardt and Fanzo, 2014. Addressing Chronic Malnutrition through Multi-Sectoral, Sustainable Approaches: A Review of the Causes and Consequences. Frontiers in Nutrition, 1.

Royal College of Obstetricians and Gynecologists, 2010.Nutrition in pregnancy. Scientific Impact Paper no 18. London, September 2010.

Schjoldager JG, Paidi MD, Lindblad MM, Birck MM, Kjaergaard AB, Dantzer V, et al., 2015, Materal vitamin $C$ deficiency during pregnancy results in transient fetal and placental growth retardation in guinea pigs. Eur J Nutr.; 54:667-76.

WHO., 2012 Guideline: Daily iron and folic acid supplementation in pregnant women. Geneva, World Health Organization.

Williamson CS,2006. Nutrition in pregnancy. In: British Nutrition Foundation. Nutrition Bulletin ;31: 28-59.

Wilson RL, Bianca-Miotto T, Leemaqz SY, Grzeskowiak LE, Dekker GA, and Roberts CT., 2018, Early pregnancy maternal trace mineral status and the association with adverse pregnancy outcome in a cohort of Australian women. Journal of Trace Elements in Medicine and Biology. ; 46:103-9.

World Health Organization.,2002. Iron and folate supplementation.Integrated Management of Pregnancy and Childbirth.Standards for Maternal and Neonatal Care.

Ji Y, Wu Z, Dai Z, Wang X, Li J, Wang B, et al., 2017. Fetal and neonatal programming of postnatal growth and feed efficiency in swine. Journal of Animal Science and Biotechnology; 8: 42. 